\title{
THE EFFECT OF FINANCIAL DEEPENING ON ECONOMIC GROWTH, INEQUALITY, AND POVERTY: EVIDENCE FROM 73 COUNTRIES
}

Catur Sugiyanto, Zefania Yolanda

\section{Abstract}

This study aims to analyze the effect of financial deepening on economic growth, income inequality, and poverty rates in 73 countries during the period 1991-2015. Panel data regression and the interaction of dummy variables are used to measure the effect. The results indicate that financial deepening has positive effects on economic growth, but negative effects on income inequality and poverty rates; has significant effect on economic growth in advanced economies (AEs) and significant effect on income equality and poverty rates in emerging markets and developing economies (EMDEs). These findings show that countries have to be selective in developing their financial sectors as it either can have positive or negative effect.

Keywords: financial deepening; income inequality; poverty; panel data

JEL classification: $016,130, C 23$

\section{INTRODUCTION}

A strong and stable growth in the financial sector has potential to facilitate sustainability of economic activities. Stiglitz (1998) states financial markets are a "brain" of the entire economic system on which decision making is centered and involves the allocation of resources. This is in line with basic functions of diverse and complex financial systems in the national economy, i.e. 1) mobilize and pool savings; 2) produce information about possible investments and capital allocations; 3) monitor investments and implement corporate governance; 4) facilitate trading, diversification, and risk management; 5) ease the exchange of goods and services (Levine 2004). Financial sector development can guarantee a country's financial stability through a deeper financial system with the implementation of various policy instruments to reduce the impact of shocks that are likely to occur.

Financial deepening is defined as the increase in the ratio of a country's financial assets to the gross
Prof. Catur Sugiyanto, MA., Ph.D.

(corresponding author)

Professor

Faculty of Economics and Business,

Universitas Gadjah Mada

E-mail: catur@ugm.ac.id

Postal address: Jalan Nusantara, Kampus

Universitas Gadjah Mada, Bulaksumur,

Yogyakarta, 55281

Zefania Yolanda, S.E.

Alumni

Faculty of Economics and Business,

Universitas Gadjah Mada

E-mail: zefania.yolanda31@gmail.com 
domestic product (GDP) (Moore 1986). It causes an increase in the depth of the country's financial sector. Financial deepening is a strategy for strengthening the country's economic fundamentals through the establishment of various instruments and products in the financial sector with an inclusive environment followed by the increase in the conditions of financial service alternatives that are more accessible to the public.

Claessens and Feijen (2006) and Zhuang et al. (2009) argue that a good financial sector influences economic growth, income inequality, and poverty rates of a country. The improvement of economic growth through financial deepening is related to policy deregulation in the financial market, which leads to a rise in savings volume and capital allocation as a stimulus for public productivity. Its effect can be seen in the growth of the private sector, macroeconomic stability, public sector, and households.

Financial sector growth also has impacts not only on economic growth but also on income inequality and poverty rates. Financial sector imperfections, e.g. unequal financial access, are the main determinants of increasing income inequality and poverty during the economic development process. Unequal access to finances can cause low-income communities to have limited resources for investment in human resource development, health, and production activities in an effort to get out of the poverty trap.

World Economic Outlook (WEO) (2018) classifies countries in the world into two groups, namely advanced economies (AEs) and emerging markets and developing economies (EMDEs) based on the levels of income per capita, export diversification, and the level of integration to global financial systems. The IMF 2018 reports financial sector growth by Financial Depth Index period 1991-2015 shows that the AEs group has greater financial sector deepening in financial institutions and markets compared to those in the EMDEs group. This financial deepening generates a financial system gap between the two groups during that period.

Moreover, the IMF (2017a) states the EMDEs group is able to reach more than 75 percent of global growth in output and consumption, which is double or more than that attained in the last two decades. It is therefore unsurprising that the EMDEs group is considered as an important group in the sustainability of global economy.

The conditions of income inequality in the EMDEs group show trend variations in which many countries experience declining trends although gaps in access to education, health, and financial still exist. In the AEs group, income inequality between the rich and the poor is widening (Dabla-Norris et al. 2015). The phenomenon of income inequality relates to the multidimensional fundamental problem in each country, i.e. poverty. A small change in income distribution will lead to a big change in poverty (Naschold 2002). The world development indicators (WDI) data in 2018 shows the proportion of the population living on less than $\$ 1.90$ per day in both of groups fluctuates each year with a declining trend in the period 1991-2015.

These findings underline the need to examine the progress of financial development in $\mathrm{AE}$ and $\mathrm{EMDE}$ countries, as the decision to liberalize their financial sectors may have unintended effect. This paper provides evidence of the effect of the financial deepening on economic growth, income inequality, and poverty rates in 32 countries in the AEs group and 41 countries in EMDEs group during the period 1991-2015. It shows that financial deepening has positively affected economic growth and negatively affected income inequality and poverty rates. The rest of this paper is structured as follows. Section 2 explores relevant literature. Section 3 sets out the methods. Then, Section 4 elaborates the results and the discussion. The last section concludes.

\section{THE EFFECT OF FINANCIAL DEEPENING ON ECONOMIC GROWTH, INCOME INEQUALITY AND POVERTY RATES}

Previous studies have provided mixed evidence about the effects of financial deepening on economic growth, income inequality, and poverty rates. King and Levine (1993) find that the financial sector growth is able to increase the rate of economic growth. Odhiambo (2007) shows that financial sector growth has an effect on economic growth through the hypothesis proof of demand-following (causality from economic growth to the financial sector growth) and supply-leading (causality from financial sector growth to economic growth) in each of the countries studied. However, Chang (2002) and Gries, Kraft, and Meierrieks (2009) present conflicting findings which suggest that the demand-following and supply-leading hypotheses are not found in the countries studied; they also show a small correlation between financial deepening and economic growth. Samargandi, Fidrmuc, and Ghosh (2015) also argue that financial sector growth has a negative effect on economic growth in middleincome countries.

Clarke, Xu, and Zou (2006), Beck, Demirgüç-Kunt, and Levine (2007), Hamori and Hashiguchi (2012), and 
$\mathrm{Li}$ and $\mathrm{Yu}$ (2014) show financial sector growth has a potential to decrease income inequality. Financial sector growth is able to decreasing income inequality because it 1) has a disproportionately positive effect on relatively poor populations; 2 ) pushes the growth rate from the poorest quintile income share; and 3) reduces the proportion of the population living on less than \$1 per day faster (Beck, Demirgüç-Kunt, and Levine 2007). Law and Tan (2009) additionally state that the financial sector has a weak and insignificant effect on reducing income inequality. Contrariwise, Haan and Sturm (2016) find financial sector growth indicators improve income inequality. Improving the quality of institutions, economic growth, and maintaining a low inflation rate are the other factors that are more helpful in alleviating income inequality (Law and Tan 2009).

Then, Odhiambo (2009a) finds that financial sector growth followed by economic growth can reduce poverty rates. The contribution of the financial sector growth on poverty reduction is also reported by Jalilian and Kirkpatrick (2005), Jeanneney and Kangni (2008), and Udin et al. (2014). The effect of financial deepening on the reduction of poverty rates depends on financial sector indicators or proxies used (Odhiambo 2009b). However, Donou-Adonsou and Sylwester (2016) show that financial sector has no significant effect on poverty reduction based on indicators used.

\section{METHODS}

\subsection{Data}

The data used in this study is a panel data covering 32 countries in AEs and 41 countries in EMDEs, in 19912015, reported by the Global Financial Development Database (GFDD), the World Bank's WDI, and the Standardized World Income Inequality Database (Solt 2016).

This paper uses four financial sector depth indicators, i.e. 1) the percentage of deposited money to GDP (DMBA) (Clarke, Xu, and Zou 2006); 2) the percentage of liquid liabilities to GDP (LL) (Gries, Kraft, and Meierrieks 2009); 3) the percentage of domestic credit to private sector to GDP (DCP) (Jalilian and Kirkpatrick, 2005; Clarke, Xu, and Zou 2006; Beck, Demirgüç-Kunt, and Levine 2007; Jeanneney and Kpodar 2006; Law and Tan 2009; Li and Yu 2014; Samargandi, Fidrmuc, and Ghosh 2015; Haan and Sturmc 2016), and 4) the percentage of stock market capitalization to GDP (SMC) (Law and Tan 2009; Park and Shin 2015). Based on the values of GFDD in 2012, the percentage of deposited money, liquid liabilities, and domestic credit to private sector to GDP, are depth indicators in financial institutions; while the percentage of stock capitalization to GDP is a depth indicator in financial markets. The greater proportion of loans and savings in the public implies a deeper penetration of the financial sector in the national economy.

The real GDP per capita is used as an economic growth indicator (Murinde and Eng 1994; Clarke, Xu, and Zou 2006; Gries, Kraft, and Meierrieks 2009). The GINI coefficient based on disposable income is used as the gap indicator (Park and Shin 2015). Poverty headcount-ratio is used as the poverty rate indicator (Beck, Demirgüç-Kunt, and Levine 2007). Additionally, this paper uses some control variables such as the share of the merchandise trade to the GDP as the globalization proxy, the consumer price index (CPI), the share of the final government consumption expenditure to the GDP as the government role in the market proxy, the gross enrollment ratio (primary) as the human capital growth proxy, the share of the labor in the agricultural sector to the total labor as the proxy for the traditional sector, and the share of the export of high-tech products to the export of manufactured products as a proxy for the modern sector. The real GDP and GDRP per capita are also used as control variables as proxies of the economic development level, especially for model estimation related to income inequality and poverty rates.

\subsection{Method of analysis}

This paper refers to two previous researchers, namely by King and Levine (1993) and Beck, Demirgüç-Kunt, and Levine (2007). The model used to determine the effect of financial deepening on economic growth is in line with that of King and Levine (1993). Meanwhile, the model purposed to determine the effect of financial deepening on income inequality and poverty is in line with that proposed by Beck, Demirgüç-Kunt, and Levine (2007).

Moreover, the model in this study is modified based on the research by Sahay and Bredenkamp (2015). We use three dummy variables to measure the effect of financial deepening on three main dependent variables in each country group, continental region, and condition when the crisis occurred (in 1998 and 2008) in 73 countries. The dummy variables measure the differences in the impacts across different country groups, the crisis, and the continental region (models 1.b, 2.b, and 3.b). 
The models are specified in the following equations.

\section{Model 1 (economic growth)}

Model 1.a $\quad$ lngdp_capita ${ }_{i, t}=\beta_{0}+\beta_{1} F D_{i, t}+\beta_{2} X_{i, t}+\varepsilon_{i, t}$

Model 1.b $\quad$ lngdp_capita $a_{i, t}=\beta_{0}+\beta_{1} F D_{i, t}+\beta_{2}\left(F D_{i, t} \times\right.$ Interact $\left._{i}\right)+\beta_{3} X_{i, t}+\varepsilon_{i, t}$

\section{Model 2 (income inequality)}

Model 2. a $\quad$ gini $_{i, t}=\beta_{0}+\beta_{1} F D_{i, t}+\beta_{2}$ lngdp_capita $_{i, t}+\beta_{3} X_{i, t}+\varepsilon_{i, t}$

Model 2. b gini $_{i, t}=\beta_{0}+\beta_{1} F D_{i, t}+\beta_{2}\left(F D_{i, t} \times\right.$ Interact $\left._{i}\right)+\beta_{3} X_{i, t}+\varepsilon_{i, t}$

\section{Model 3 (poverty rates)}

Model 3.a poverty_headcount ${ }_{i, t}=\beta_{0}+\beta_{1} F D_{i, t}+\beta_{2}$ lngdp_capita $_{i, t}+\beta_{3} X_{i, t}+\varepsilon_{i, t}$

Model 3.b poverty_headcount $_{i, t}=\beta_{0}+\beta_{1} F D_{i, t}+\beta_{2}\left(F D_{i, t} \times\right.$ Interact $\left._{i}\right)+\beta_{3} X_{i, t}+\varepsilon_{i, t}$

where Ingdp_capita is the natural logarithm of the real GDP per capita; gini is the GINI coefficient; poverty_headcount is the poverty headcount ratio; FD describes the four financial deepening indicator variables (DMBA, LL, DCP, and SMC); FD 'Interact is an interaction of dummy variable with financial deepening indicator variables; $X$ is the control variable covering Ingdp_capita (specifically for models 2 and 3), trade (the trade openness), CPI (the consumer price index), government (the percentage of government consumption on final products expenditure to the GDP), school_primary (the gross enrollment ratio-primary education), employment_agriculture (the labor in the agricultural sector as a proportion of the total labor), and export_manufacture (the percentage of exports of high-tech products to the exports of manufactured products); $i$ is for the country; $t$ is the time code; and is error term. Models 1.b, 2.b, and 3.b consist of the three different and separate estimations based on the three dummy interaction variables used.

The Stata version 13 is used to estimate the equation. The selection random vs fixed effect model is based on the Chow test, the Lagrange Multiplier (LM) test, and the Hausman test.

\section{RESULTS AND DISCUSSION}

The three model selection tests ${ }^{1}$ conclude that the fixed effect model is the best estimation model for economic growth (model 1), followed by the income inequality model (model 2 ), and then the poverty rate model (model 3) except for model 3.b with dummy interaction of continental region is better to use the random effect model. The following are the panel data regression results based on the economic growth model (model 1 ), the income inequality model (model 2 ), and the poverty rate model (model 3 ) in 73 countries.

\subsection{Model 1 (Impact of Financial Deepening on Economic Growth)}

Table 4.1 explains that the percentage of banks' assets in the form of deposited money to GDP is the only financial deepening indicator with a significant negative effect on economic growth in the economic growth model (model 1.a). High bank deposits represent a large amount of idle funds as a large percentage of the deposits in banks are actually not distributed entirely into productive activities that could improve the economy. Such negative sign shows that a high deposit is followed by a low level of credit distribution from savers to borrowers. The other three financial deepening indicators, i.e. the percentage of liquid liabilities to GDP, the percentage of domestic credit to private sector to GDP, and the percentage of stock market capitalization to GDP have a positive and significant effect on economic growth. These findings can prove that a higher degree of financial deepening in a country results in the effective use of resources (funds), hence boosting economic growth.

1 Results from the test can be obtained from the author upon request. 
Table 4.1 The results of panel data regression for models 1.a and 1.b

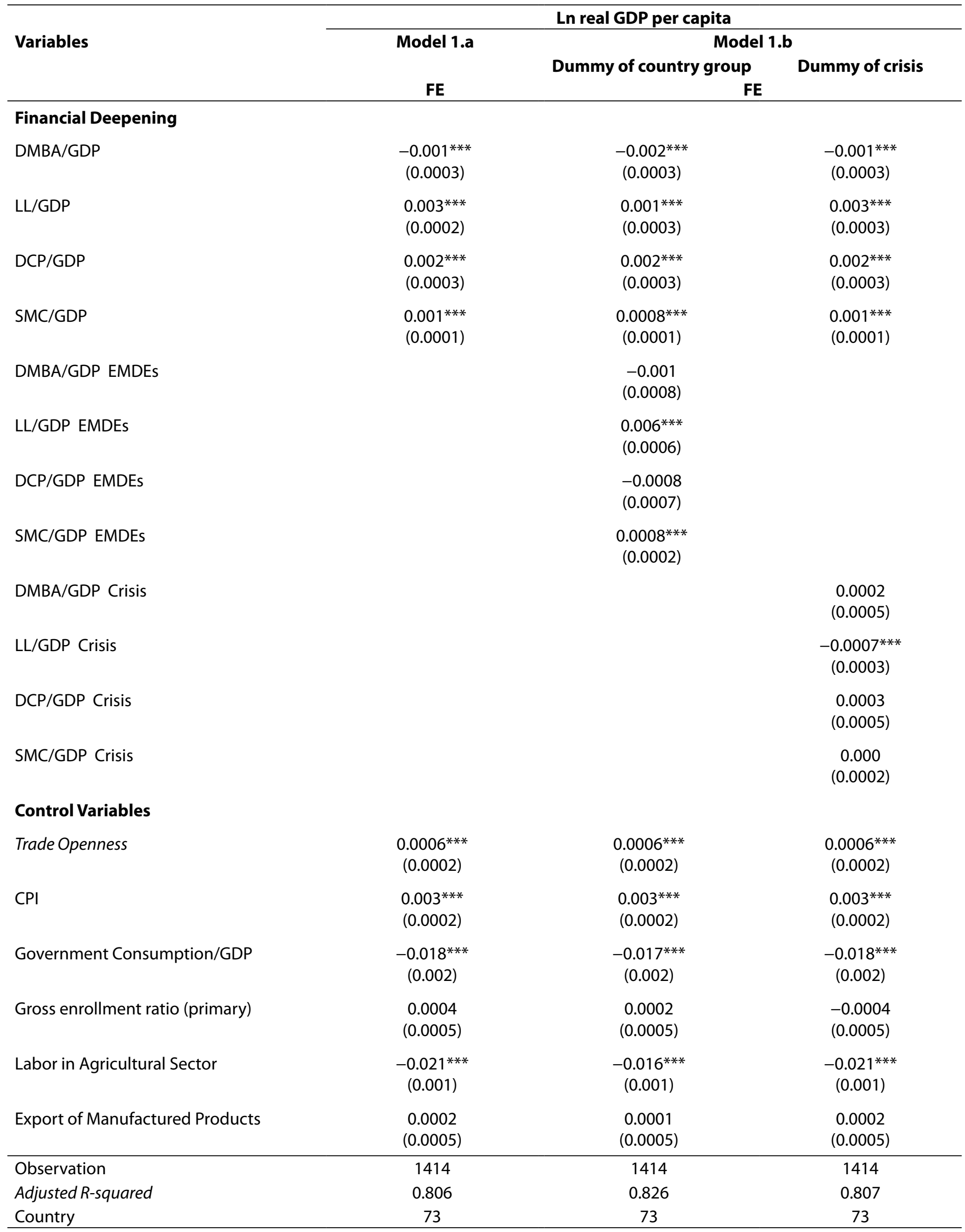

Source: Stata 13 output, processed (2018)

Note:*** significant at level $1 \%$; ${ }^{* *}$ significant at level 5\%; ${ }^{*}$ significant at level $10 \%$; The numbers in () indicate the standard error 
In estimating the model using dummy interactions of the country groups, the coefficients of the percentage of deposited money to GDP, percentage of liquid liabilities to GDP, percentage of domestic credit to private sector to GDP, and percentage of stock market capitalization to GDP show the effect of the four financial deepening indicator variables on economic growth in the AEs group. The percentage of deposited money to GDP is found to have a significant negative effect on economic growth, while the percentage of liquid liabilities to GDP, percentage of domestic credit to private sector to GDP, and percentage of stock market capitalization to GDP have a positive and significant effect on economic growth in the EMDEs group.

The interaction between financial deepening indicator variables and EMDEs indicates differences in the effect of financial sector depth on economic growth within the EMDEs and AEs groups. Based on the calculation of the marginal effect, the magnitude of the effect of the percentage of deposited money to GDP and percentage of domestic credit to private sector to GDP on economic growth in the AEs group are found to be more inelastic than in the EMDEs group, while the effect of the percentage of liquid liabilities to GDP and the percentage of stock market capitalization to GDP on economic growth in the AEs group is found to be more elastic than EMDEs group. Overall, financial deepening indicators have more significant effect on economic growth in the AEs group than in the EMDEs group so it can be concluded that financial deepening has more potential for increasing economic growth in the AEs group.

Meanwhile, the estimation model using a dummy variable for crisis show the effect of the above four financial deepening indicator variables on economic growth when there is no crisis. The percentage of deposited money to GDP is found to have a negative and significant effect on economic growth, while the percentage of liquid liabilities to GDP, the percentage of domestic credit to private sector to GDP, and the percentage of stock market capitalization to GDP, all have a positive and significant effect on economic growth when there is no crisis. The interaction between the financial deepening indicator variables and economic conditions during crisis indicates differences in the effect of the financial sector depth on economic growth between conditions of crisis and conditions in which there is no crisis. The marginal effect calculation shows that the magnitude of the effect of the percentage of deposited money to GDP and percentage of domestic credit to private sector to GDP on economic growth when there is no crisis is found to be more elastic than the magnitude of effect of those variables during a crisis; while the effect of the percentage of liquid liabilities to GDP on economic growth when there is no crisis is found to be more inelastic than during a crisis. Then, the effect of percentage of stock market capitalization to GDP on economic growth is found to have no effect both during crisis and when there is no crisis. Overall, the effect of financial deepening on economic growth by country or crisis group tends to be relatively weak. More financial deepening indicators are found to have a significant effect on economic growth when there is no crisis. These findings suggest that financial sector growth must be accompanied by various shock-absorbing events or instruments to dampen the crisis, so that financial sector indicators can develop and progress effectively.

In all economic growth models (models 1.a and 1.b), it can be seen that economic growth is influenced positively and significantly by trade openness and CPI. Otherwise, the final total government consumption of GDP and labor in agricultural sector has a negative and significant effect on economic growth. There are some important findings that need to be emphasized from the control variable estimation results. First, $\mathrm{CPI}$ is found to have a significant positive effect on economic growth because, in principle, the inflation rate does not always have a negative impact on the economy. An inflation rate could encourage entrepreneurs to expand their production due to the rising price of goods they sell so that the profit obtained also rises. Second, the negative correlation found between the final government consumption and the economic growth is caused by the crowding out effect. There is an increase in government consumption accompanied by a decrease in the level of private investment so that the impact of the increase in government consumption on GDP becomes zero, and a negative impact is realized on macroeconomic stability. This phenomenon occurs when expansion fiscal policy cause increases interest rates thus reducing investment. In addition, large government consumption sometimes can also cover the positive effects of government investments.

\subsection{Model 2 (Impact of Financial Deepening on Income Inequality)}

Table 4.2 reveals that there is no significant effect of the percentage of deposited money to GDP, the percentage of liquid liabilities to GDP, and the percentage of domestic credit to private sector to GDP on income inequality. In the financial deepening and income inequality model (model 2.a), this study finds positive and significant correlation between the percentage 
Table 4.2 The results of panel data regression for models 2.a and 2.b

\begin{tabular}{|c|c|c|c|}
\hline \multirow{4}{*}{ Variables } & \multicolumn{3}{|c|}{ GINI Index } \\
\hline & \multirow{3}{*}{$\begin{array}{c}\text { Model 2.a } \\
\text { FE }\end{array}$} & \multicolumn{2}{|c|}{ Model 2.b } \\
\hline & & Dummy of country group & Dummy of crisis \\
\hline & & FE & \\
\hline \multicolumn{4}{|l|}{ Financial Deepening } \\
\hline DMBA/GDP & $\begin{array}{c}0.004 \\
(0.004)\end{array}$ & $\begin{array}{l}-0.002 \\
(0.005)\end{array}$ & $\begin{array}{c}0.003 \\
(0.005)\end{array}$ \\
\hline LL/GDP & $\begin{array}{l}-0.005 \\
(0.004)\end{array}$ & $\begin{array}{c}0.004 \\
(0.004)\end{array}$ & $\begin{array}{l}-0.005 \\
(0.004)\end{array}$ \\
\hline $\mathrm{DCP} / \mathrm{GDP}$ & $\begin{array}{c}0.006 \\
(0.004)\end{array}$ & $\begin{array}{l}0.01^{* *} \\
(0.005)\end{array}$ & $\begin{array}{c}0.007 \\
(0.004)\end{array}$ \\
\hline SMC/GDP & $\begin{array}{c}0.004^{* * *} \\
(0.002)\end{array}$ & $\begin{array}{l}0.003 \\
(0.002)\end{array}$ & $\begin{array}{l}0.003^{*} \\
(0.002)\end{array}$ \\
\hline DMBA/GDP EMDEs & & $\begin{array}{c}0.057^{* * *} \\
(0.012)\end{array}$ & \\
\hline LL/GDP EMDEs & & $\begin{array}{c}-0.05^{* * *} \\
(0.009)\end{array}$ & \\
\hline DCP/GDP EMDEs & & $\begin{array}{l}-0.05^{* * *} \\
(0.01)\end{array}$ & \\
\hline SMC/GDP EMDEs & & $\begin{array}{c}0.004 \\
(0.004)\end{array}$ & \\
\hline DMBA/GDP Crisis & & & $\begin{array}{c}0.002 \\
(0.007)\end{array}$ \\
\hline LL/GDP Crisis & & & $\begin{array}{c}-0.0005 \\
(0.004)\end{array}$ \\
\hline DCP/GDP Crisis & & & $\begin{array}{l}-0.004 \\
(0.007)\end{array}$ \\
\hline SMC/GDP Crisis & & & $\begin{array}{c}0.004 \\
(0.003)\end{array}$ \\
\hline \multicolumn{4}{|l|}{ Control Variables } \\
\hline Ln(real GDP per capita) & $\begin{array}{c}2.803^{* * *} \\
(0.419)\end{array}$ & $\begin{array}{l}3.62^{* * *} \\
(0.436)\end{array}$ & $\begin{array}{c}2.811^{* * *} \\
(0.421)\end{array}$ \\
\hline Trade Openness & $\begin{array}{l}0.0006 \\
(0.003)\end{array}$ & $\begin{array}{c}-0.0001 \\
(0.003)\end{array}$ & $\begin{array}{l}0.0005 \\
(0.003)\end{array}$ \\
\hline CPI & $\begin{array}{c}-0.019^{* * *} \\
(0.003)\end{array}$ & $\begin{array}{c}-0.023^{* * *} \\
(0.003)\end{array}$ & $\begin{array}{c}-0.019^{* * *} \\
(0.003)\end{array}$ \\
\hline $\begin{array}{l}\text { Government Consumption/ } \\
\text { GDP }\end{array}$ & $\begin{array}{l}0.066^{* *} \\
(0.027)\end{array}$ & $\begin{array}{l}0.063^{* *} \\
(0.027)\end{array}$ & $\begin{array}{l}0.067^{* *} \\
(0.027)\end{array}$ \\
\hline $\begin{array}{l}\text { Gross enrollment ratio } \\
\text { (primary) }\end{array}$ & $\begin{array}{c}0.01 \\
(0.008)\end{array}$ & $\begin{array}{c}0.008 \\
(0.008)\end{array}$ & $\begin{array}{c}0.01 \\
(0.008)\end{array}$ \\
\hline Labor in Agricultural Sector & $\begin{array}{c}0.071^{* * *} \\
(0.017)\end{array}$ & $\begin{array}{c}0.052^{* * *} \\
(0.017)\end{array}$ & $\begin{array}{l}0.071^{* * *} \\
(0.017)\end{array}$ \\
\hline $\begin{array}{l}\text { Export of Manufactured } \\
\text { Products }\end{array}$ & $\begin{array}{l}0.02^{* * *} \\
(0.007)\end{array}$ & $\begin{array}{l}0.02^{* * *} \\
(0.007)\end{array}$ & $\begin{array}{c}0.021^{* * *} \\
(0.007)\end{array}$ \\
\hline Observation & 1386 & 1386 & 1386 \\
\hline Adjusted $R$-squared & 0.1 & 0.138 & 0.1 \\
\hline Country & 73 & 73 & 73 \\
\hline
\end{tabular}

Source: Stata 13 output, processed (2018)

Note: ${ }^{* * *}$ significant at level $1 \% ;{ }^{* *}$ significant at level 5\%; ${ }^{*}$ significant at level $10 \%$; The numbers in ( ) indicate the standard error 
of stock market capitalization to GDP and income inequality. As there are many people (the poor) who do not hold stock and the growth of the stock is in line with higher economic growth, the increasing number of shares will actually widen income inequality. The finding that the percentage of stock market capitalization to GDP indicator adversely affects income inequality is in line with research conducted by Law and Tan (2009) and Park and Shin (2015).

In the income inequality model with dummy interaction (model 2.b), only the percentage of domestic credit to private sector to GDP has a positive and significant effect on income inequality in AEs group, while the other indicators have no significant effect. The magnitude of the effect of the percentage of deposited money to GDP and the percentage of stock market capitalization to GDP on the income gap in the EMDEs is found to be more inelastic than that in the AEs group, whereas the effects of the percentage of liquid liabilities to GDP and the percentage of domestic credit to private sector to GDP on the income gap are found to be more elastic in the EMDEs group than in the AEs group. Overall, more financial deepening indicators have a more significant effect on the income gap in the EMDEs group than in the AEs group.

A positive and significant correlation was only found between the percentage of stock market capitalization to GDP and income inequality when there is no crisis. The magnitude of the effect of the percentage of deposited money to GDP and the percentage of liquid liabilities to GDP on income inequality is more elastic, while the magnitude of the effect of the percentage of domestic credit to private sector to GDP and the percentage of stock market capitalization to GDP on income inequality is more inelastic as there is no crisis. The financial sector works more effectively when the economy is in a stable condition. For the whole financial deepening and income inequality model (models 2 .a and 2.b), real GDP per capita, share of final government consumption to GDP, labor in agricultural sector, and export of manufactured products are found to have a positive and significant influence on income inequality, while CPI has a negative correlation.

The interesting findings are seen in the effects of real GDP per capita, CPI, final government consumption to GDP, and export of manufactured products on income inequality. The positive relationship between real GDP per capita and income inequality is probably caused by the increasing income of some society groups. Therefore, it can be said that the national economy cakes are enjoyed unevenly by all society groups. A sluggish economy due to low inflation rate causes a negative effect of CPI on income inequality.
The low inflation rate causes the price goods to be low hence producers become less eager to increase their production. This condition has the potential of increasing inequality because there are some community groups whose business continuity is affected, subsequently affecting their income.

The government consumption has an effect not only on reducing economic growth, but also on increasing income inequality. The crowding out effect and non-productive consumption are some of the factors that widen the inequality. The increase in income inequality is also motivated by the export of manufactured products, because a rise in export volume will only increase the welfare or income of workers in the sector of trade in manufactured products, which increases the likelihood of rising inequality.

\subsection{Model 3 (Impact of Financial Deepening on Poverty Rates)}

Table 4.3 shows that the percentage of the deposited money to GDP, the percentage of liquid liabilities to GDP, and the percentage of stock market capitalization to GDP have no significant correlation on poverty rates. The only financial indicator that has a positive and significant effect on poverty rates (model 3.a) is the percentage of domestic credit to private sector to GDP. This is likely due to the large amount of idle funds, which is followed by the low level of credit distribution from savers to borrowers.

The four financial deepening indicators are not found to have a significant effect on poverty rates in the AEs group. The magnitude of the effect of the percentage of deposited money to GDP and the percentage of domestic credit to private sector to GDP on poverty rates in the EMDEs group are found to be more inelastic than those in the AEs group, while the effect of the percentage of liquid liabilities to GDP and percentage of stock market capitalization to GDP is more elastic in the EMDEs group than in the AEs group. Financial deepening indicators are found to have a more significant effect on the poverty rates in the EMDEs group than in the AEs group.

The model with the dummies reveals that the percentage of domestic credit to private sector to GDP, is the only financial deepening indicator that has a positive and significant relationship with poverty rates when no crisis occurs. The effect of the percentage of deposited money to GDP and percentage of stock market capitalization to GDP on poverty rates is more inelastic, and the effect of the percentage of liquid liabilities to GDP and the percentage of domestic credit to private sector to GDP is more elastic when there is 
Table 4.3 The results of panel data regression for models 3.a and 3.b

\begin{tabular}{|c|c|c|c|}
\hline \multirow{4}{*}{ Variables } & \multicolumn{3}{|c|}{ Poverty Headcount Ratio } \\
\hline & \multirow{3}{*}{$\begin{array}{c}\text { Model 3.a } \\
\text { FE }\end{array}$} & \multicolumn{2}{|c|}{ Model 3.b } \\
\hline & & Dummy of country group & Dummy of crisis \\
\hline & & FE & \\
\hline \multicolumn{4}{|l|}{ Financial Deepening } \\
\hline DMBA/GDP & $\begin{array}{c}0.006 \\
(0.022)\end{array}$ & $\begin{array}{l}-0.000 \\
(0.025)\end{array}$ & $\begin{array}{c}0.006 \\
(0.023)\end{array}$ \\
\hline LL/GDP & $\begin{array}{c}0.016 \\
(0.019)\end{array}$ & $\begin{array}{c}0.034 \\
(0.022)\end{array}$ & $\begin{array}{l}0.016 \\
(0.02)\end{array}$ \\
\hline $\mathrm{DCP} / \mathrm{GDP}$ & $\begin{array}{l}0.043^{* *} \\
(0.019)\end{array}$ & $\begin{array}{c}0.017 \\
(0.022)\end{array}$ & $\begin{array}{l}0.042^{* *} \\
(0.019)\end{array}$ \\
\hline SMC/GDP & $\begin{array}{c}-0.012 \\
(0.01)\end{array}$ & $\begin{array}{c}0.007 \\
(0.012)\end{array}$ & $\begin{array}{c}-0.011 \\
(0.01)\end{array}$ \\
\hline DMBA/GDP EMDEs & & $\begin{array}{c}0.035 \\
(0.052)\end{array}$ & \\
\hline LL/GDP EMDEs & & $\begin{array}{l}-0.069 \\
(0.042)\end{array}$ & \\
\hline DCP/GDP EMDEs & & $\begin{array}{l}0.098^{* *} \\
(0.045)\end{array}$ & \\
\hline SMC/GDP EMDEs & & $\begin{array}{c}-0.059^{* * *} \\
(0.021)\end{array}$ & \\
\hline DMBA/GDP Crisis & & & $\begin{array}{l}-0.003 \\
(0.046)\end{array}$ \\
\hline LL/GDP Crisis & & & $\begin{array}{c}0.001 \\
(0.013)\end{array}$ \\
\hline DCP/GDP Crisis & & & $\begin{array}{c}0.006 \\
(0.049)\end{array}$ \\
\hline SMC/GDP Crisis & & & $\begin{array}{l}-0.006 \\
(0.015)\end{array}$ \\
\hline \multicolumn{4}{|l|}{ Control Variables } \\
\hline Ln(real GDP per capita) & $\begin{array}{c}-8.59^{* * *} \\
(2.019)\end{array}$ & $\begin{array}{l}-8.124^{* * *} \\
(2.138)\end{array}$ & $\begin{array}{l}-8.623^{* * *} \\
(2.042)\end{array}$ \\
\hline Trade Openness & $\begin{array}{l}0.028^{* *} \\
(0.014)\end{array}$ & $\begin{array}{l}0.041^{* * *} \\
(0.014)\end{array}$ & $\begin{array}{l}0.028^{* *} \\
(0.014)\end{array}$ \\
\hline CPI & $\begin{array}{c}-0.026^{* *} \\
(0.013)\end{array}$ & $\begin{array}{c}-0.043^{* * *} \\
(0.013)\end{array}$ & $\begin{array}{c}-0.026^{* *} \\
(0.013)\end{array}$ \\
\hline $\begin{array}{l}\text { Government Consumption/ } \\
\text { GDP }\end{array}$ & $\begin{array}{l}-0.088 \\
(0.135)\end{array}$ & $\begin{array}{l}-0.025 \\
(0.135)\end{array}$ & $\begin{array}{l}-0.088 \\
(0.136)\end{array}$ \\
\hline $\begin{array}{l}\text { Gross enrollment ratio } \\
\text { (primary) }\end{array}$ & $\begin{array}{c}0.042 \\
(0.035)\end{array}$ & $\begin{array}{l}0.058^{*} \\
(0.035)\end{array}$ & $\begin{array}{c}0.042 \\
(0.035)\end{array}$ \\
\hline Labor in Agricultural Sector & $\begin{array}{c}0.588^{* * *} \\
(0.08)\end{array}$ & $\begin{array}{c}0.549^{* * *} \\
(0.08)\end{array}$ & $\begin{array}{c}0.587^{* * *} \\
(0.08)\end{array}$ \\
\hline $\begin{array}{l}\text { Export of Manufactured } \\
\text { Products }\end{array}$ & $\begin{array}{c}0.025 \\
(0.028)\end{array}$ & $\begin{array}{c}0.002 \\
(0.029)\end{array}$ & $\begin{array}{c}0.024 \\
(0.028)\end{array}$ \\
\hline Observation & 680 & 680 & 680 \\
\hline Adjusted R-squared & 0.466 & 0.491 & 0.466 \\
\hline Country & 72 & 72 & 72 \\
\hline
\end{tabular}

Source: Stata 13 output, processed (2018)

Note: ${ }^{* *}$ significant at level $1 \%$; ${ }^{* *}$ significant at level $5 \%$; ${ }^{*}$ significant at level $10 \%$; The numbers in ( ) indicate the standard error 
Table 4.4 The results of panel data regression for models 1.b, 2.b, and 3.b

\begin{tabular}{|c|c|c|c|}
\hline Variables & $\begin{array}{c}\text { Ln real GDP per capita } \\
\text { Model 1.b } \\
\text { FE }\end{array}$ & $\begin{array}{l}\text { GINI coefficient } \\
\text { Model 2.b } \\
\text { FE }\end{array}$ & $\begin{array}{c}\text { Poverty Headcount Ratio } \\
\text { Model 3.b } \\
\text { RE }\end{array}$ \\
\hline \multicolumn{4}{|l|}{ Financial Deepening } \\
\hline DMBA/PDB & $\begin{array}{c}-0.001^{* * *} \\
(0.0004)\end{array}$ & $\begin{array}{l}0.014^{* *} \\
(0.006)\end{array}$ & $\begin{array}{c}0.039 \\
(0.027)\end{array}$ \\
\hline LL/PDB & $\begin{array}{l}0.002^{* * *} \\
(0.0003)\end{array}$ & $\begin{array}{l}-0.007 \\
(0.004)\end{array}$ & $\begin{array}{c}0.03^{*} \\
(0.017)\end{array}$ \\
\hline DCP/PDB & $\begin{array}{l}0.002^{* * *} \\
(0.0004)\end{array}$ & $\begin{array}{l}-0.002 \\
(0.006)\end{array}$ & $\begin{array}{l}-0.009 \\
(0.024)\end{array}$ \\
\hline SMC/PDB & $\begin{array}{l}0.001^{* * *} \\
(0.0002)\end{array}$ & $\begin{array}{c}-0.0002 \\
(0.006)\end{array}$ & $\begin{array}{c}0.004 \\
(0.018)\end{array}$ \\
\hline DMBA/PDB Asia & $\begin{array}{c}-0.002^{* *} \\
(0.0007)\end{array}$ & $\begin{array}{c}-0.032^{* * * *} \\
(0.01)\end{array}$ & $\begin{array}{l}-0.107 \\
(0.065)\end{array}$ \\
\hline LL/PDB Asia & $\begin{array}{l}0.005^{* * *} \\
(0.0006)\end{array}$ & $\begin{array}{c}0.027^{* * *} \\
(0.009)\end{array}$ & $\begin{array}{c}-0.096^{* *} \\
(0.042)\end{array}$ \\
\hline DCP/PDB Asia & $\begin{array}{c}0.0009 \\
(0.0006)\end{array}$ & $\begin{array}{l}0.001 \\
(0.01)\end{array}$ & $\begin{array}{c}0.181^{* * *} \\
(0.051)\end{array}$ \\
\hline SMC/PDB Asia & $\begin{array}{l}0.00005 \\
(0.0009)\end{array}$ & $\begin{array}{c}0.026^{* * *} \\
(0.004)\end{array}$ & $\begin{array}{c}-0.088^{* * *} \\
(0.025)\end{array}$ \\
\hline DMBA/PDB America & $\begin{array}{c}0.001 \\
(0.001)\end{array}$ & $\begin{array}{l}0.027^{*} \\
(0.014)\end{array}$ & $\begin{array}{c}0.047 \\
(0.053)\end{array}$ \\
\hline LL/PDB America & $\begin{array}{l}0.0002 \\
(0.001)\end{array}$ & $\begin{array}{c}-0.052^{* * *} \\
(0.015)\end{array}$ & $\begin{array}{l}-0.081 \\
(0.054)\end{array}$ \\
\hline DCP/PDB America & $\begin{array}{c}-0.002^{* * *} \\
(0.0007)\end{array}$ & $\begin{array}{l}0.004 \\
(0.01)\end{array}$ & $\begin{array}{c}0.05 \\
(0.043)\end{array}$ \\
\hline SMC/PDB America & $\begin{array}{l}0.0007^{* *} \\
(0.0003)\end{array}$ & $\begin{array}{c}-0.014^{* * *} \\
(0.005)\end{array}$ & $\begin{array}{c}-0.057^{* *} \\
(0.026)\end{array}$ \\
\hline DMBA/PDB Afrika & $\begin{array}{c}0.002 \\
(0.002)\end{array}$ & $\begin{array}{l}-0.034 \\
(0.028)\end{array}$ & $\begin{array}{l}-0.11 \\
(0.214)\end{array}$ \\
\hline LL/PDB Afrika & $\begin{array}{c}0.006^{* * *} \\
(0.001)\end{array}$ & $\begin{array}{c}-0.062^{* * * *} \\
(0.02)\end{array}$ & $\begin{array}{l}-0.151 \\
(0.136)\end{array}$ \\
\hline DCP/PDB Afrika & $\begin{array}{l}-0.002 \\
(0.002)\end{array}$ & $\begin{array}{l}0.059 * * \\
(0.024)\end{array}$ & $\begin{array}{l}0.29^{* *} \\
(0.138)\end{array}$ \\
\hline SMC/PDB Afrika & $\begin{array}{c}-0.001^{* *} \\
(0.0005)\end{array}$ & $\begin{array}{c}0.004 \\
(0.007)\end{array}$ & $\begin{array}{l}-0.051 \\
(0.047)\end{array}$ \\
\hline DMBA/PDB Australia-Oceania & $\begin{array}{c}0.002 \\
(0.005)\end{array}$ & $\begin{array}{c}-0.073^{* *} \\
(0.038)\end{array}$ & $\begin{array}{l}0.06 \\
(2.8)\end{array}$ \\
\hline LL/PDB Australia-Oceania & $\begin{array}{l}-0.003 \\
(0.002)\end{array}$ & $\begin{array}{l}0.078^{* * *} \\
(0.038)\end{array}$ & $\begin{array}{l}-0.151 \\
(3.254)\end{array}$ \\
\hline DCP/PDB Australia-Oceania & $\begin{array}{c}0.002 \\
(0.005)\end{array}$ & $\begin{array}{c}0.031 \\
(0.069)\end{array}$ & $\begin{array}{c}0.092 \\
(0.868)\end{array}$ \\
\hline SMC/PDB Australia-Oceania & $\begin{array}{l}-0.001 \\
(0.001)\end{array}$ & $\begin{array}{c}0.006 \\
(0.015)\end{array}$ & $\begin{array}{l}-0.021 \\
(0.812)\end{array}$ \\
\hline Control Variables & & & \\
\hline Ln(real GDP per capita) & & $\begin{array}{c}3.014 * * * \\
(0.427)\end{array}$ & $\begin{array}{c}-2.494^{* *} \\
(1.214)\end{array}$ \\
\hline Trade Openness & $\begin{array}{c}0.0006^{* * * *} \\
(0.0002)\end{array}$ & $\begin{array}{c}0.002^{* * *} \\
(0.003)\end{array}$ & $\begin{array}{l}0.027^{* * *} \\
(0.013)\end{array}$ \\
\hline CPI & $\begin{array}{l}0.004^{* * *} \\
(0.0002)\end{array}$ & $\begin{array}{c}-0.016^{* * *} \\
(0.003)\end{array}$ & $\begin{array}{c}-0.064^{* * * *} \\
(0.01)\end{array}$ \\
\hline $\begin{array}{l}\text { Government Consumption/ } \\
\text { GDP }\end{array}$ & $\begin{array}{c}-0.019^{* * *} \\
(0.002)\end{array}$ & $0.052^{*}$ & -0.031 \\
\hline Gross enrollment ratio & -0.0005 & 0.011 & $0.057^{*}$ \\
\hline (primary) & $(0.0005)$ & $(0.008)$ & $(0.034)$ \\
\hline Labor in Agricultural Sector & $\begin{array}{c}-0.017^{* * * *} \\
(0.001)\end{array}$ & $\begin{array}{c}0.104^{* * *} \\
(0.018)\end{array}$ & $\begin{array}{c}0.541^{* * *} \\
(0.072)\end{array}$ \\
\hline $\begin{array}{l}\text { Export of Manufactured } \\
\text { Products }\end{array}$ & $\begin{array}{l}-0.0004 \\
(0.0005)\end{array}$ & $\begin{array}{c}0.023^{* * *} \\
(0.007)\end{array}$ & $\begin{array}{c}0.019 \\
(0.028)\end{array}$ \\
\hline Observation & 1414 & 1386 & 680 \\
\hline Adjusted R-squared & 0.829 & 0.185 & 0.49 \\
\hline Country & 73 & 73 & 72 \\
\hline
\end{tabular}

Source: Stata 13 output, processed (2018)

Note: *** significant at level 1\%; ** significant at level 5\%; significant at level $10 \%$; The numbers in ( ) indicate the standard error 
no crisis. Overall, the real GDP per capita and CPI have a negative and significant effect, while trade openness and labor in the agricultural sector have a positive and significant effect on the poverty rates.

\subsection{Results for models 1, 2, and 3 by the inter- action of the continental region dummy}

Table 4.4 shows models with the interaction of the continental region dummy (models 1.b, 2.b, and 3.b), for which the variable coefficients of the percentage of deposited money to GDP, percentage of liquid liabilities to GDP, percentage of domestic credit to private sector to GDP, and percentage of stock market capitalization to GDP, are the effects of the four financial deepening indicators on each dependent variable in Europe. In the economic growth model with the interaction of the continental region dummy (model 1.b), more financial deepening indicators are found to have a significant effect on economic growth in Europe. The percentage of deposited money to GDP has a negative and significant effect, whereas the percentage of liquid liabilities to GDP, the percentage of domestic credit to private sector to GDP, and the percentage of stock market capitalization to GDP have a positive and significant effect on economic growth in Europe.

In the income inequality model with the interaction of the continental region dummy (model 2.b), more financial deepening indicators are found to have significant influence on income inequality in Asia and America. The effect of the percentage of liquid liabilities to GDP, percentage of domestic credit to private sector to GDP, and the percentage of stock market capitalization to GDP on income inequality in Asia is more elastic than that in Europe, whereas the effect of the percentage of deposited money to GDP on income inequality in Asia is more inelastic than that in Europe. Then, the effect of the percentage of deposited money to GDP and the percentage of domestic credit to private sector to GDP on income inequality is more elastic, while the effect of percentage of liquid liabilities to GDP and percentage of stock market capitalization to GDP is more inelastic in America than in Europe.

Then, in the poverty rate model with the interaction of the continental region dummy (model 3.b), more financial deepening indicators are found to have significant effects on poverty rates in Asia. The effect of the percentage of domestic credit to private sector to GDP is more elastic, while the effect of the percentage of deposited money to GDP, percentage of liquid liabilities to GDP, and percentage of stock market capitalization to GDP on poverty rates are more inelastic in
Asia than in Europe. Overall, these results imply that different financial sector developments have difference impacts on the economy; financial sector development could increase economic growth or alleviate income inequality and poverty problem in accordance with the conditions and policy targets in each region.

\section{CONCLUSION}

There are several conclusions that can be drawn from the findings above. First, more financial deepening indicators are found to have a significant effect on economic growth than on income gap and poverty rates in the 73 countries. Financial deepening is able to improve economic growth through the percentage of liquid liabilities to GDP, percentage of domestic credit to private sector to GDP, and percentage of stock market capitalization to GDP indicators. Additionally, financial deepening can increase the income gap through percentage of stock market capitalization to GDP indicator and increase the poverty rates through percentage of domestic credit to private sector to GDP indicator in 73 countries.

Second, more financial deepening indicators are found to have a significant influence on economic growth in the AEs group than in the EMDEs group. Yet, more financial deepening indicators have a significant effect on the income gap and poverty rates in the EMDEs group than in AEs group. Economic growth can be improved by financial deepening through the percentage of liquid liabilities to GDP, percentage of domestic credit to private sector to GDP, and percentage of stock market capitalization to GDP indicators in the AEs. The percentage of liquid liabilities to GDP and percentage of domestic credit to private sector to GDP indicators can also reduce the income gap in the EMDEs group. Finally, financial deepening is found to have two effects on poverty rates in the EMDEs group, namely increasing poverty based on the percentage of domestic credit to private sector to GDP indicator, and reducing poverty based on the percentage of stock market capitalization to GDP indicator.

These findings reveal that financial deepening has a greater effect on income inequality and poverty in the EMDEs, hence the right financial sector development policies are needed. Most countries in the EMDEs group still have barriers that hinder the development of the financial sector to greater effectiveness and efficiency, i.e. low access to financial services and weak financial stability. Weak financial stability can be caused by the position of the state financial sector that is still in the development stage, making it susceptible to stress triggered by increasingly growing 
and integrated financial services.

Therefore, the policy implications that can be applied to EMDEs group are related to efforts made to increasing financial literacy with more inclusive development. Improvement of financial literacy can be done through public education on financial products and services and eliminating obstacles to financial access. In addition, technological improvement in accessing financial services are also needed, which can be used to educate the public about the financial sector through e-learning.

\section{REFERENCES}

Beck, T., Demirgüç-Kunt, A. and Levine, R. 2007. Finance, inequality and the poor. Journal of Economic Growth 12: 27-49.

Chang, T. 2002. Financial development and economic growth in Mainland China: a note on testing demand following or supply-leading hypothesis. Applied Economics Letters 9 (13): 869-873.

Claessens, S. and Feijen, E. 2006. Financial sector development and the millennium development goals. World Bank Working Paper 89.

Clarke, G. R., Xu, L. C. and Zou, H.-f. 2006. Finance and income inequality: what do the data tell us?. Southern Economic Journal 72 (3): 578-596.

Dabla-Norris, E., Kochhar, K., Suphaphiphat, N., Ricka, F. and Tsounta, E. 2015. Causes and consequences of income inequality: a global perspective. IMF Staff Discussion Note.

Donou-Adonsou, F. and Sylwester, K. 2016. Financial development and poverty reduction in developing countries: new evidence from banks and microfinance institutions. Review of Development Finance 6: 82-90.

Gries, T., Kraft, M. and Meierrieks, D. 2009. Linkages between financial deepening, trade openness, and economic development: causality evidence from Sub-Saharan Africa. World Development 37 (12): 1849-1860.

Haan, J. D. and Sturm, J.-E. 2016. Finance and income inequality: a review and new evidence. DNB Working Paper 530.

Hamori, S. and Hashiguchi, Y. 2012. The effect of financial deepening on inequality: some international evidence. Journal of Asian Economics 23: 353-359.

International Monetary Fund. 2017a. Financial deepening for macroeconomic stability and sustained growth (database online). https://www.imf.org/external/np/res/dfidimf/ topic5.htm (accessed Mei 1, 2018).

International Monetary Fund. 2017b. World Economic Outlook April 2017: Gaining Momentum? Washington, DC: International Monetary Fund.
International Monetary Fund. 2018. Financial development index database (database online). http://data. imf.org/?sk=F8032E80-B36C-43B1-AC26-493C5B1CD33Bandsld= 1480712464593 (accessed Maret 29, 2018).

International Monetary Fund. World economic outlookreal GDP growth (database online). https://www.imf. org/external/datamapper/NGDP_RPCH@WEO/OEMDC/ ADVEC/WEOWORLD (accessed Mei 8, 2018).

Jalilian, H. and Kirkpatrick, C. 2005. Does financial development contribute to poverty reduction?. The Journal of Development Studies 41 (4): 636-656.

Jeanneney, S. G. and Kpodar, K. 2008. Financial development and poverty reduction: can there be a benefit without a cost?. IMF Working Paper WP/08/62.

King, R. G. and Levine, R. 1993. Finance and growth: Schumpeter might be right. The Quarterly Journal of Economics 108 (3): 717-737.

Law, S. H. and Tan, H. B. 2009. The role of financial development on income inequality in Malaysia. Journal of Economic Development 34.

Levine, R. 2004. Finance and growth: theory and evidence. NBER Working Paper 10766.

$\mathrm{Li}, \mathrm{J}$. and $\mathrm{Yu}, \mathrm{H}$. 2014. Income inequality and financial reform in Asia: the role of human capital. Applied Economics 46 (24): 2920-2935.

Moore, B. J. 1986. Inflation and financial deepening. Journal of Development Economics 20: 125-133.

Murinde, V. and Eng, F. S. 1994. Financial development and economic growth in Singapore: demand-following or supply-leading?. Applied Financial Economics 4 (6): 391-404.

Naschold, F. 2002. Why inequality matters for poverty. Briefing Paper 2.

Odhiambo, N. M. 2007. Supply-leading versus demand-following hypothesis: empirical evidence from three SSA Countries. African Development Bank.

Odhiambo, N. M. 2009a. Finance-growth-poverty nexus in South Africa: a dynamic causality linkage. The Journal of Socio-Economics 38: 320-325.

Odhiambo, N. M. 2009b. Financial deepening and poverty reduction in Zambia: an empirical investigation. International Journal of Social Economics 37 (1): 41-53.

Park, D. and Shin, K. 2015. Economic growth, financial development, and income inequality. ADB Economics Working Paper Series 441.

Sahay, R. and Bredenkamp, H. 2015. Rethinking financial deepening: stability and growth in emerging markets. International Monetary Fund.

Samargandi, N., Fidrmuc, J. and Ghosh, S. 2015. Is the relationship between financial development and economic growth monotonic? evidence from a sample of middleincome countries. World Development 68: 66-81.

Solt, F. 2016. The standardized world income inequality database. Social Science Quaterly. 
Stiglitz, J. E. 1994. The role of the state in financial markets. Proceedings of the World Bank Annual Conference on Development Economics 1993: 19-61.

Uddin, G. S., Shahbaz, M., Arouri, M. and Teulon, F. 2014. Financial development and poverty reduction nexus: a cointegration and causality analysis in Bangladesh. Economic Modelling 36: 405-412.

World Bank. 2017. Growth (database online). http://www. worldbank.org/en/topic/ macroeconomics/brief/ growth (accessed Maret 19, 2018).

World Bank Open Data. 2018. Poverty headcount ratio at $\$ 1.90$ a day (2011 PPP) (\% of population) (online database). https://data.worldbank.org/indicator/SI.POV. DDAY (accessed Maret 29, 2018).
World Economic Outlook (WEO). 2018. Frequently asked questions world economic outlook (WEO) (database online). https://www.imf.org/external/pubs/ft/weo/faq. htm (accessed Mei 5, 2018).

Yolanda, Zefania 2018. Pengaruh Financial Deepening terhadap Pertumbuhan Ekonomi, Ketimpangan Pendapatan, dan Tingkat Kemiskinan; studi kasus 73 negara dan 33 Provinsi di Indonesia, Skripsi, tidak dipublikasikan.

Zhuang, J., Gunatilake, H., Niimi, Y., Khan, M. E., Jiang, Y., Hasan, R. et al. 2009. Financial sector development, economic growth, and poverty reduction: a literature review. ADB Economics Working Paper Series 173. 